\title{
On the spread of the European catfish (Silurus glanis) in the Iberian Peninsula: first record in the Llobregat river basin
}

\author{
Lluís Benejam, Joaquim Carol, Josep Benito \& Emili García-Berthou*
}

Institut d'Ecologia Aquàtica, Universitat de Girona, E-17071 Girona, Catalonia, Spain. Tel.: +34 650640914. Fax: +34 972418 150. Personal web page: http://ciencies.udg.es/egb.html

* Corresponding author: emili.garcia@udg.es

\begin{abstract}
On the spread of the European catfish (Silurus glanis) in the Iberian Peninsula: first record in the Llobregat river basin The first record of the European catfish (Silurus glanis L. 1758) introduced to the Llobregat river basin (NE Spain) is reported. We captured one individual of this silurid fish species (of a total of 541 fish) in La Baells reservoir on 30 August 2006. Given the low catchability of this fish species, the popularity among some anglers, and old rumours on this introduction, we hypothesize that this species has been present in the reservoir since a few years ago, despite we did not capture it in two previous surveys. The illegal introduction of this and other exotic species to other Iberian river basins should be prevented by the Spanish administration.
\end{abstract}

Key words: Wels catfish, Siluridae, La Baells reservoir, Spain, invasive fish.

\section{RESUMEN}

Sobre la dispersión del siluro (Silurus glanis) en la Península ibérica: primera cita en la cuenca del río Llobregat

Se da la primera cita de siluro (Silurus glanis L. 1758) introducido en la cuenca del río Llobregat (Cataluña). Se capturó un individuo de esta especie de silúrido (de un total de 534 peces) en el embalse de La Baells el 30 de agosto de 2006. Dada la baja capturabilidad de este pez, su popularidad entre algunos pescadores deportivos, y viejos rumores de esta introducción, sugerimos que esta especie está presente desde hace algunos años, a pesar que no la detectamos en dos muestreos previos. La introducción ilegal de ésta y otras especies exóticas en otras cuencas ibéricas debería ser evitada por la administración española.

Palabras clave: Siluridae, embalse de La Baells, España, peces invasores.

The role of invasive species in biodiversity reduction and biotic homogenization is widely appreciated nowadays (Olden et al., 2004; Clavero \& García-Berthou, 2005; Pimentel, 2005; Strayer et al., 2006). The rate of introduction of exotic fish in the Iberian peninsula (IP) has accelerated in the last decades (Elvira \& Almodóvar, 2001; García-Berthou et al., 2005; Clavero \& GarcíaBerthou, 2006) and nowadays ca. 25 exotic fish species are naturalized (i.e. established) in the IP (for 37 native non-migratory species) and most Iberian river basins have more foreign or translocated than native species (Clavero \& García-
Berthou 2006). Recent introductions to the IP include the Siberian sturgeon Acipenser baeri (Elvira \& Almodóvar 2001), the topmouth gudgeon Pseudorasbora parva (Caiola \& de Sostoa 2002), and the common bream Abramis brama (Benejam et al., 2005).

The European catfish (Silurus glanis L. 1758) was introduced to the IP around 1974 at Mequinensa and Riba-roja reservoirs, Ebro river basin (Doadrio 2002). It has also been introduced to a reservoir in the Tajo river basin (Doadrio 2002) and in 2003 we recorded it in Susqueda reservoir (Ter river basin) (Carol et al., 2003) and 
later on also in Sau reservoir. The aim of this note is to report its introduction in a new river basin and to alert on the probable (illegal) introduction to further Iberian river basins.

During a fish survey on 30 August 2006, we captured one individual of this species in La Baells reservoir, NE Spain $\left(42^{\circ} 7^{\prime} 40^{\prime \prime} \mathrm{N}\right.$, $\left.1^{\circ} 52^{\prime} 46^{\prime \prime} \mathrm{E}\right)$. Among 499 fish caught by littoral electrofishing and 42 by gillnetting (stretched mesh ranging $29-253 \mathrm{~mm}$ ) at $5-10 \mathrm{~m}$ of depth, only one was of European catfish $(0.2 \%$ of the electrofishing catches), of $76 \mathrm{~mm}$ of total length.

Although we did not detect this species in previous surveys of the La Baells reservoir in April 2003 (total catch $=635$ fish) and August 2004 (total catch $=440$ fish) and one might argue that European catfish may have not been established in La Baells reservoir, we believe this is not case for several reasons. First, this fish species is not easy to catch by conventional scientific fishing techniques and is usually underestimated. This was the case in the Ter river basin, where we only captured a few individuals of catfish (a single individual of 458 fish in 2003 and 7 of 884 fish in 2004) during the surveys (with electrofishing and gillnets) in the reservoirs of Sau and Susqueda, despite that experimental purse-seine fisheries at Sau reservoir have later demonstrated that catfish were common in the pelagic waters of the reservoir, where it was barely captured by gillnets. Second, our record confirms informal chats by anglers available on the internet (by searching "siluro"+"baells" you get notices of catfish in La Baells as old as May 1999 and some hints on how it was introduced). We had heard similar rumours for Sau reservoir before actually catching it. Other reasons to suspect establishment are the large size of the reservoir (maximum surface area of 367 ha, maximum capacity of $115.4 \mathrm{hm}^{3}$ ) and the relatively low fishing effort that we used and the abundance of this species along the last $133 \mathrm{~km}$ of the lower reaches of Ebro river (from Mequinensa reservoir to the Ebro delta).

Unfortunately, fish introduction continues to be largely uncontrolled by fish management authorities and little is done to improve education and management practices. La Baells reservoir is the largest in the Llobregat river basin, which jointly with Sau and Susqueda reservoirs are the main water suppliers to the Barcelona region, so this introduction might have socioeconomic implications for water quality in addition to the environmental costs. Once an exotic fish species has established in a large, connected ecosystem, it will be often be very difficult to eradicate it. Prevention of further introductions and translocations to new river basins should be much easier, economical, and effective. Unless profound changes in current Spanish fisheries management and policy are undertaken, we predict the introduction of this and other exotic species to the rest of Iberian river basins, where many fish species endemic to the IP are already endangered. This is particularly probable for the catfish given the economic benefits (for a few people) that it has yielded in some Ebro reservoirs and the impunity of previous introductions. Doadrio (2002) already alerted on the probable spread of this species due to current interests among anglers and since then we have recorded it in two new river basins. How many more will come?

\section{ACKNOWLEDGEMENTS}

This study was financed by the Spanish Ministry of Science and Technology (REN2003-00477) and the Catalan Ministry of Universities, Research and Information Society (DURSI, Catalan Government Distinction Award for University Research 2004 to EGB). LB and JC held doctoral fellowships from the University of Girona.

\section{REFERENCES}

BENEJAM, L., J. CAROL, C. ALCARAZ \& E. GARCÍA-BERTHOU. 2005. First record of the common bream (Abramis brama) introduced to the Iberian Peninsula. Limnetica, 24: 273-274.

CAIOLA, N. \& A. DE SOSTOA. 2002. First record of the Asiatic cyprinid Pseudorasbora parva in the Iberian Peninsula. J. Fish Biol., 61: 1058-1060. 
CAROL, J., L. BENEJAM, Q. POU, L. ZAMORA y E. GARCÍA-BERTHOU. 2004. Primera citació de brema blanca (Abramis bjoerkna) a Catalunya i noves introduccions de peixos exòtics (Alburnus alburnus, Sander lucioperca i Silurus glanis) en diverses conques catalanes. Butll. Inst. Cat. Hist. Nat., 71: 135-136.

CLAVERO, M. \& E. GARCÍA-BERTHOU. 2005. Invasive species are a leading cause of animal extinctions. Trends Ecol. Evol., 20: 110.

CLAVERO, M. \& E. GARCÍA-BERTHOU. 2006. Homogenization dynamics and introduction routes of invasive freshwater fish in the Iberian Peninsula. Ecol. Appl., 16: 2313-2324.

DOADRIO, I. (ed.) 2002. Atlas y libro rojo de los peces continentales de España. Ministerio de Medio Ambiente, Madrid. 374 pp.

ELVIRA, B. \& A. ALMODÓVAR. 2001. Freshwater fish introductions in Spain: facts and figures at the beginning of the 21 st century. J. Fish Biol., 59: 323-331.

GARCÍA-BERTHOU, E., C. ALCARAZ, Q. POUROVIRA, L. ZAMORA, G. COENDERS \& C. FEO. 2005. Introduction pathways and establishment rates of invasive aquatic species in Europe. Can. J. Fish. Aquat. Sci., 62: 453-463.

OLDEN, J. D., N. L. POFF, M. R. DOUGLAS, M E. DOUGLAS \& K. D. FAUSCH. 2004. Ecological and evolutionary consequences of biotic homogenization. Trends Ecol. Evol., 19: 18-24.

PIMENTEL, D., R. ZUNIGA \& D. MORRISON. 2005. Update on the environmental and economic costs associated with alien-invasive species in the United States. Ecological Economics., 52: 273-288.

STRAYER, D. L., V. T. EVINER, J. M. JESCHKE \& M. L. PACE. 2006. Understanding the long-term effects of species invasions. Trends Ecol. Evol., 21: 645-651. 
